\title{
SNRPN wt Allele
}

National Cancer Institute

\section{Source}

National Cancer Institute. SNRPN wt Allele. NCI Thesaurus. Code C75577.

Human SNRPN wild-type allele is located in the vicinity of $15 q 11.2$ and is approximately $596 \mathrm{~kb}$ in leng th. This allele, which encodes small nuclear ribonucleoprotein-associated protein $\mathrm{N}$, may play a role in mRNA splicing. Mutations in this gene are associated with Prader-Willi Syndrome. 